well-established, and the most frequently occurring, type of such co-operation. More recently he has made important contributions to the analysis of complex spectra corresponding to various stages of ionization -particularly those of metals prominent in celestial spectra.

Prof. Russenc's work is marked throughout by a breadth of interest and a clearness of apprehension of essentials which place him among the greatest men of science of the time. There is scarcely a branch of astronomy (with the possible exception of problems peculiar to the extra-galactic nebulæ) which has not attracted his attention and become elucidated thereby. He has recently advanced some very suggestive ideas relating to the origin of the solar system, and his text-book on astronomy, written in association with his colleagues, Profs. R. S. Dugan and J. Q. Stewart, is unique in its kind. He travels freely among the American observatories, and has for many years been regarded as a kind of unofficial ambassador-at-large, co-ordinating work of various types and often taking an active part in the solution of the problems encountered. His vivid personality is one of the most conspicuous and characteristic features of astronomical conferences, and the welldeserved honour now accorded him of foreign membership of the Royal Society will give universal satisfaction.

\section{The German Expedition to Nanga Parbat}

Everyone must sympathize with the Germans who have met with disaster, for a second time, in an attempt to climb Nanga Parbat. In 1934 three members, including the leader, lost their lives on the mountain in a blizzard and one died from illness; added to this, six of their faithful porters also lost their lives. Now news has come that the second German expedition has met with an even greater disaster, seven out of nine members, including the leader, Dr. Karl Wein, together with nine porters, having been overwhelmed by an avalanche at Camp IV. Details of what exactly happened are not yet to hand, but almost at the same time as the news of the disaster was telegraphed an article appeared in The Times of June 22 from Dr. Karl Wein, professor of geography at the University of Munich, dated June 6 from the Base Camp. From this it seems the present expedition is following the same route as that of 1934 . On June 5 it had reached Camp III, which in the former expedition was at a height of $19,400 \mathrm{ft}$., while the 'trek' to Camp IV, $20,300 \mathrm{ft}$., had been made on the following day. In this account Dr. Wein describes a great avalanche crashing down the face of Nanga Parbat, but which with the exception of several stray fragments did not reach Camp II, 17,550 ft., which was being pitched at the time. The rush of air caused tents to be "blown over, tent poles snapped and strong canvas torn". All the members of the party seem to have been thoroughly experienced mountaineers. We shall await with interest details of this, probably the greatest, of Himalayan disasters.

\section{Powers of the National Trust}

The Bill by which it is proposed to extend the powers of the National Trust was considered by the Select Committee of the House of Commons on unopposed Bills on June 17, Capt. R. C. Bourne being in the chair. The object of the Bill is to put into operation the scheme of the Trust for the preservation of houses of historic or æsthetic interest in private ownership, which in part was inspired by legislation framed for this purpose in France. It will enable the Trust to take over and save from breaking up large country houses and estates, while allowing the donor and his family and descendants to continue to occupy, provision being made for the public to have access to them. In addition, the Bill provides for enabling the National Trust to acquire and hold small sites of five acres in extent for the purpose of preserving "view-points"; to enter into agreements with owners restricting the use of land, and empowers local authorities to co-operate with the Trust. By this legislation the National Trust will be placed in a much stronger position in regard to what must be regarded as its most useful function-the safeguarding and ensuring the preservation of sites which on account of their outstanding archæological, historical or æsthetic interest, are of national, or even of international importance. It will be relieved in no small measure of the constant necessity of urgent and hurried 'last-minute' appeals, which recent rapid land development has made unavoidable, but of which in the end there is danger that the public may become a little weary. The Trust will now be enabled by the Bill to concentrate on appealing to the general public for the preservation of sites of which the national importance will be most readily appreciated, or for which no other provision is possible.

\section{Indians of Canada}

AN example of the variation in method in dealing with the less advanced races of different parts of the Empire, to which reference is made on another page of this issue of NATURE (see p. 1083), is afforded in a recent survey of conditions among the Indians of Canada by the Hon. T. A. Crerar, M.P., Minister of Mines and Resources of the Dominion of Canada. Indian administration in Canada is dorninated by the twofold aim of protection and advancement. The Indians, at one time rapidly decreasing in numbers and regarded as a doomed race, are now on the up-grade. Since 1927, when they had fallen to 104,000 , they have increased to 112,000 . This increase is attributed largely to the improved medical benefits they now receive and the greater attention given to hygiene. They live on reservations, of which there are two thousand of varying size, running from a few acres up to five hundred square miles, the total area being $5,170,000$ acres, of which 220,000 acres is under cultivation. A fund of fourteen million dollars, accruing from the sale of Indian lands, mining rights, etc., is administered by the Government entirely for Indian benefit. The cultural condition of the Indians depends almost entirely on 
their geographical environment. In the East, they are farmers, and although many are very poor and all suffering from the effects of the economic depression, they differ little in condition from their white agricultural neighbours. In the northern hinterland they are hunters and trappers, and have suffered severely from white competition, and the same applies to some extent to the salmon fishing communities of the North-West coast; but the tribes of the Plains region (Alberta) who lost their livelihood with the extinction of the bison and became farmers and ranchers, have in many instances achieved prosperity in two generations. Finally, it may be added, it is possible for an Indian to become enfranchised on certain conditions, and to cease to rank legally as an Indian.

\section{Statistics of Unemployment}

THE report of the Ministry of Labour for 1936 directs attention to the exceptionally sharp rise in the numbers available for employment, which increased by 270,000 between July 1935 and July 1936, due mainly to a rise in the numbers of persons aged sixteen years resulting from the increased birth-rate in the immediate post-War years. Against this there was a large increase in the numbers in employment, which in December 1936 reached the highest level recorded since comparable statistics have been kept$11,132,000$ as against 10,629,000 in December 1935 . There was also a marked decrease in the numbers unemployed, the number of persons registering as unemployed at employment exchanges in December 1936 being $1,629,000$ as against $1,869,000$ in December 1935. This total includes 69,000 'casuals', 195,000 'temporarily stopped' and 82,000 'juveniles'. Analysis of the age distribution of unemployed men and women indicates that the problem of finding work for those in the older age groups is predominantly one affecting men, and that age proves a handicap to obtaining employment when younger persons are available. Severe unemployment continued in the coal mining industry, but on a lower level than in 1935. The position improved in all the metal trade groups; in the cotton industry, unemployment over the whole year was $15 \cdot 7$ per cent compared with $20 \cdot 9$ per cent in 1935. The position improved in the wool industry but remained severe in the jute industry and in textile finishing. Most other industries showed improvement.

There was a marked increase in the number of persons transferred from the depressed areas compared with previous years, and the proportionate increase in the number of families assisted to re-settle was even more notable. In view of the improved employment position, the whole country was thrown open in instructional centre recruitment, preference in allocation to centres being given to men from areas of heavy and prolonged unemployment. Some expansion in physical training is also reported. Juvenile employment conditions also improved, but there was no indication of a general revival of the apprenticeship system of engaging labour. Shortages of juvenile labour relate particularly to boys and girls in the 14-15 age group, and there was a widespread tendency to raise the starting wage of learners, particularly in unskilled and non-progressive employment. The policy of industrial transference of juveniles was continued in certain areas, as well as arrangements for vocational training and guidance and placing in employment. Reference is also made to progress in the decentralization of the work of the Ministry.

\section{Russian Trans-polar Flight}

THReE Soviet airmen, flying a single-engined 960 h.p. monoplane, "Ant 25", left Moscow on June 18 on a non-stop flight to San Francisco via the North Pole. According to the New York correspondent of The Times, they were compelled by poor visibility to land at Pierson Field, Vancouver Barracks, in the State of Washington, on June 20, when within six hundred miles of their goal. They had been in the air for 63 hours 17 minutes, and are stated to have passed near the Pole at an altitude of 14,000 ft. The three airmen, MM. Byelyakoff, Chkaloff and Baidukoff, have been decorated with the Soviet Order of Merit, and Mr. Roosevelt, in a congratulatory message to the Soviet Ambassador in the United States, referred to the flight as a "historic feat".

\section{Palæolithic Implements from Bombay}

Palfolithro implements from the island of Salsette, north of Bombay, of considerable importance as demonstrating for the first time the presence of a palæolithic culture in this region of India, have been placed on exhibition in the British Museum (Bloomsbury). This series of implements is the result of three years' excavations carried out by Lieut.-Commander Todd in Pleistocene deposits of alternating gravel and clay. The implements are of indurated shale and come from various levels of stratification. They include Lower, Middle and Upper Palæolithic types, which, however, differ considerably from previous palæolithic finds in India. The principal site is a quarry at Khandivli, situated some $100 \mathrm{ft}$. above sea-level near the foothills running up to the moun. tainous interior. Mesolithic implements occur as surface finds and also in the caves of Padan not far away, where they are associated with rock engravings. Diagrams of the geological conditions and photographs of the sites are also exhibited with the implements.

\section{Research on Diseases of Farm Animals}

AN extensive programme of investigation into the cause and prevention of disease in farm animals is being undertaken by the Animal Diseases Research Association at Moredun, near Edinburgh, under the direction of Dr. J. Russell Greig. It has for some time become apparent that the existing laboratories and animal accommodation at Moredun were in. sufficient for the Research Association's rapidly extending work, and Treasury sanction has recently been given to the recommendation of the Agricultural Research Council and the Department of Agriculture 